\title{
Development of a Liquid Formulation of Lignolytic Fungi for Increased Shelf Life
}

\author{
K. S. Sruthy and Livleen Shukla* \\ Division of Microbiology, ICAR-IARI, New Delhi-12, India \\ *Corresponding author
}

\begin{abstract}
A B S T R A C T
Keywords

Lignolytic,

Consortium, Fungi,

formulation, PVP

Article Info

Accepted:

12 December 2020

Available Online:

10 January 2021

High lignin content is one of the major reasons for the recalcitrance of rice stubble, and microbial degradation is an eco-friendly method to manage this large fraction of rice residue, which accumulates in the field. In the present study, three fungal isolates with promising lignolytic potential were selected to develop and optimize a suitable liquid formulation comprising a lignolytic consortium of fungi. For making the liquid formulation, $3 \%$ jaggery medium containing $0.05 \%$ yeast extract was selected as the base. Various polyvinylpyrrolidone (PVP) concentrations from $0-2.5 \%$ were added into the medium and tested for viability of the consortium, and the isolates individually for one year. The study revealed that PVP at $1.5 \%, 2 \%$ and $2.5 \%$ concentration maintained the viability of the cells for one year. Individual isolates as well as consortium followed a similar trend. However, in the treatment which did not contain PVP, viable cells were found to reduce sharply after three months. So, the study revealed that a liquid formulation containing $3 \%$ jaggery, $0.05 \%$ yeast extract and $1.5 \%$ PVP is most suitable for better shelf life and viability of the consortium.
\end{abstract}

\section{Introduction}

Rice is categorized as the most important human food crop in the world, accounting for $20 \%$ of global ingested calories. Paddy cultivation produces 660 million tons of rice, along with 800 million tons of residues (Borah et al., 2016). Rice stubble constitutes part of the root system and just above the ground portion and is highly rich in cellulose and lignin. It is incorporated into the soil during field preparation and allowed to decompose (Vibha and Sinha, 2007), but it has very high lignin and cellulose content, particularly the roots. Lignin constitutes a relatively stable component of soil organic matter because of its recalcitrant chemical structure and its resistance to microbial degradation. Lignin is reported to slow down the mineralization of nutrients from crop residues on the time scale of a cropping season. Lignin concentration and the lignin/ $\mathrm{N}$ ratio are widely used as indicators for the degradability of litter. The disposal of rice stubbles after harvest of rice crop remains a major concern in all rice-growing areas. The states follow rice-wheat cropping patterns like in Punjab and Haryana, rice stubble 
management is a burning issue (Kumar and Joshi. 2015). The most common practice adopted by farmers to manage rice stubble and straw is burning, especially in areas where the next crop is grown in a short time. This method offers less time for its incorporation into the soil for decomposition. Burning of straw leads to emission of trace gases like $\mathrm{CO}_{2}, \mathrm{CH}_{4}, \mathrm{CO}, \mathrm{N}_{2} \mathrm{O}$ and $\mathrm{SO}_{2}$. Moreover, a large amount of particulates are also released through rice stubble burning. Approximately, India emits 144719 mg of total particulate matter from open-field burning of rice straw annually (Kumar et al., 2015). For addressing this issue, there is a need for developing hyperlignolytic consortium specifically for recalcitrant rice stubble. Competitiveness and viability of mycelial products during preservation also requires food base for survival. (San Martin et al., 1997; Lewis and Papavizas, 1985; Vikineswary et al., 1997). Generally, liquid formulations sustain the shelf-life up to 18-24 months (Sharma et al., 2010). In this study, optimization of a formulation for the consortium of lignolytic fungal isolates was undertaken. These fungal strains have been isolated and identified from degrading rice stubble previously (Sruthy, 2020).

\section{Materials and Methods}

Lignolytic fungal isolates, LN-1 LN-14 and LN-19, already identified as Aspergillus terreus, Aspergillus fumigatus and Alternaria spp. (Sruthy, 2020) were used for developing a formulation. All the three isolates were coinoculated, two/three at a time, on the same PDA plates and checked for any zone of inhibition or incompatibility while growing. Seven days old fungal isolates were then inoculated on media containing $3 \%$ jaggery and $0.05 \%$ yeast extract. The cultures were blended individually after 10 days of growth and different concentrations of filter sterilized polyvinlypyrrolidone (PVP) was added. $30 \mathrm{ml}$ of each of the sets were transferred into screw cap tubes and three tubes were withdrawn from the lot at monthly intervals and checked for the viable count, by serial dilution and plating. For mixed cultures, equal quantity of three cultures were mixed together and the same procedure was followed.

\section{Results and Discussion}

Development of formulation requires a suitable substrate whose nutrients can sustain the growth of the organism, over long periods of storage and transport to the place of use from manufacturing units. In the present investigation, routinely used substrates such as jaggery and yeast extract were selected, as they are accessible, effective carbon sources and economically feasible for mass scale production (Vijayendra et al., 2004). Besides nutrition, the formulation needs to be amended with a polymer. A wide variety of polymers, such as PVP are used for inoculant production, as they can restrict heat transfer and high water activities and improve shelf life (Mugnier and Jung, 1985). PVP is a well known polymer, having a hydrophobic alkyl backbone along with hydrophilic pendant groups, thereby readily absorbs up to $40 \%$ of water by its weight. Its use as a binder is because in solution, it has excellent wetting properties, readily forms films, or useful as a coating (Hiremath et al., 2019).

The viable count of isolate $\mathrm{LN}-1$ at different concentrations of PVP for 1 year is depicted in Table $1 \&$ figure 1 . The results indicated that the viable count of isolate LN-1 dropped rapidly in formulations which had no added PVP (from 10.66 to $5.57 \log _{10} \mathrm{CFU}$ ), $0.5 \%$ PVP (from 10.66 to $6.88 \log _{10} \mathrm{CFU}$ ) and $1 \%$ PVP (from 10.66 to $8.20 \log _{10} \mathrm{CFU}$ ) from third month onwards. In the formulation not containing PVP, viable spores were not detected from $7^{\text {th }}$ month onwards. In formulations added with $0.5 \%$ and $1 \%$ PVP, 
viable spore was not detected from $9^{\text {th }}$ and $11^{\text {th }}$ month respectively. The formulation with PVP added at $1.5 \%, 2 \%$ and $2.5 \%$ were able to maintain the viable cells up to 12 months $\left(\log _{10} \mathrm{CFU} / \mathrm{ml}\right.$ was found to be more than or equal to 4 in this treatment at $12^{\text {th }}$ month). So, the formulation added with $1.5 \%$ PVP was identified to be the most suitable for better shelf life of the consortium.In a related study, a liquid formulation for Azospirillum brasilense developed by Vendan and
Thangaraju (2006) in the presence of PVP, reported $10^{8}$ cells/ml up to 10 months.

Similarly, Table 2 and figure 2 show the viable count of lignolytic isolate $\mathrm{LN}-14$ on different concentrations of PVP. A similar result was obtained in isolate $\mathrm{LN}-14$, in which formulations with $1.5 \%, 2 \%$ and $2.5 \%$ PVP have shown better shelf life as compared to other treatments.

Table.1 Viable count of isolate LN-1 at different concentrations of PVP for 1 year

\begin{tabular}{|l|l|l|l|l|l|l|l|l|l|l|l|l|l|}
\hline \multirow{2}{*}{$\begin{array}{l}\text { Concentration } \\
\text { of PVP }\end{array}$} & \multicolumn{10}{|c|}{ Viable count } \\
\cline { 2 - 17 } & 0 & 1 & 2 & 3 & 4 & 5 & 6 & 7 & 8 & 9 & 10 & 11 & 12 \\
\hline $\mathbf{0 . 5 \%}$ & 10.66 & 9.82 & 8.77 & 6.88 & 6.08 & 5.72 & 4.45 & 3.86 & 2.08 & ND & ND & ND & ND \\
\hline $\mathbf{1 \%}$ & 10.66 & 9.86 & 9.20 & 8.20 & 8.04 & 7.49 & 6.57 & 6.71 & 4.49 & 3.62 & 1.53 & ND & ND \\
\hline $\mathbf{1 . 5 \%}$ & 10.66 & 9.93 & 9.62 & 8.97 & 8.92 & 8.76 & 8.18 & 7.76 & 6.98 & 6.15 & 5.61 & 4.61 & 4.04 \\
\hline $\mathbf{2 \%}$ & 10.66 & 9.93 & 9.66 & 8.99 & 8.97 & 8.77 & 8.28 & 7.84 & 6.96 & 6.32 & 5.64 & 4.15 & 4.15 \\
\hline $\mathbf{2 . 5 \%}$ & 10.66 & 9.95 & 9.65 & 9.04 & 9.04 & 8.71 & 8.26 & 7.76 & 6.26 & 5.45 & 4.04 & 4.04 & 4.04 \\
\hline No PVP & 10.66 & 8.30 & 6.23 & 5.57 & 4.85 & 3.26 & 2.58 & ND & ND & ND & ND & ND & ND \\
\hline
\end{tabular}

Table.2 Viable count of isolate LN-14 at different concentrations of PVP for 1 year

\begin{tabular}{|c|c|c|c|c|c|c|c|c|c|c|c|c|c|}
\hline \multirow{2}{*}{$\begin{array}{l}\text { Concentration } \\
\text { of PVP }\end{array}$} & \multicolumn{13}{|c|}{ Viable count $\left(\log _{10}\right.$ of $\left.\mathrm{CFU} / \mathrm{ml}\right)$ of isolate $\mathrm{LN}-14$ in formulations at one month interval } \\
\hline & 0 & 1 & 2 & 3 & 4 & 5 & 6 & 7 & 8 & 9 & 10 & 11 & 12 \\
\hline $0.5 \%$ & 10.71 & 9.87 & 8.86 & 6.97 & 6.38 & 5.83 & 4.91 & 3.94 & 2.68 & ND & ND & ND & ND \\
\hline $1 \%$ & 10.71 & 10.00 & 9.43 & 8.43 & 8.23 & 7.67 & 6.87 & 6.89 & 4.76 & 3.83 & 1.85 & ND & ND \\
\hline $1.5 \%$ & 10.71 & 9.98 & 9.76 & 9.15 & 9.08 & 8.79 & 8.62 & 7.95 & 7.46 & 6.69 & 5.95 & 4.77 & 4.28 \\
\hline $2 \%$ & 10.71 & 9.99 & 9.69 & 9.20 & 9.15 & 8.81 & 8.64 & 7.96 & 7.51 & 6.72 & 5.86 & 4.72 & 4.08 \\
\hline $2.5 \%$ & 10.71 & 9.99 & 9.68 & 9.28 & 9.11 & 8.83 & 8.67 & 7.89 & 6.57 & 5.57 & 4.18 & 3.72 & 3.72 \\
\hline No PVP & 10.71 & 9.36 & 6.38 & 5.64 & 4.95 & 3.30 & 2.69 & 1.51 & ND & ND & ND & ND & ND \\
\hline
\end{tabular}

Table.3 Viable count of isolate LN-19 at different concentrations of PVP for 1 year

\begin{tabular}{|c|c|c|c|c|c|c|c|c|c|c|c|c|c|}
\hline \multirow[t]{2}{*}{$\begin{array}{l}\text { Concentration } \\
\text { of PVP }\end{array}$} & \multicolumn{13}{|c|}{$\begin{array}{l}\text { Viable count }\left(\log _{10} \text { of } \mathrm{CFU} / \mathrm{ml}\right) \text { of isolate } \mathrm{LN}-19 \text { in formulations at one month } \\
\text { interval }\end{array}$} \\
\hline & 0 & 1 & 2 & 3 & 4 & 5 & 6 & 7 & 8 & 9 & 10 & 11 & 12 \\
\hline $0.5 \%$ & 10.63 & 10.18 & 8.51 & 6.77 & 6.23 & 5.56 & 4.11 & 3.66 & 2.20 & ND & ND & ND & ND \\
\hline $1 \%$ & 10.63 & 10.26 & 9.26 & 8.26 & 8.11 & 7.52 & 6.28 & 6.68 & 4.45 & 3.20 & 1.43 & ND & ND \\
\hline $1.5 \%$ & 10.63 & 10.23 & 9.57 & 9.08 & 9.04 & 8.61 & 8.32 & 8.03 & 7.57 & 6.23 & 5.43 & 4.67 & 4.23 \\
\hline $2 \%$ & 10.63 & 10.28 & 9.61 & 9.04 & 8.99 & 8.59 & 8.46 & 8.04 & 7.59 & 6.36 & 5.49 & 4.79 & 4.32 \\
\hline $2.5 \%$ & 10.63 & 10.26 & 9.65 & 8.97 & 8.93 & 8.59 & 8.46 & 7.28 & 6.46 & 5.28 & 3.85 & 3.04 & 3.04 \\
\hline No PVP & 10.63 & 9.49 & 6.32 & 5.04 & 4.08 & 3.15 & 2.53 & ND & ND & ND & ND & ND & ND \\
\hline
\end{tabular}


Table.4 Viable count of consortium at different concentrations of PVP for 1 year

\begin{tabular}{|l|l|l|l|l|l|l|l|l|l|l|l|l|l|}
\hline \multirow{2}{*}{$\begin{array}{l}\text { Concentration } \\
\text { of PVP }\end{array}$} & \multicolumn{19}{|c|}{ Viable count } & \multicolumn{1}{|c|}{$\log _{\mathbf{1 0}}$ of CFU/ml) of consortium in formulations at one month interval } \\
\hline $\mathbf{0 . 5 \%}$ & 0 & 1 & 2 & 3 & 4 & 5 & 6 & 7 & 8 & 9 & 10 & 11 & 12 \\
\hline $\mathbf{1 \%}$ & 10.69 & 9.98 & 8.83 & 6.88 & 6.28 & 5.69 & 4.67 & 3.84 & 2.73 & ND & ND & ND & ND \\
\hline $\mathbf{1 . 5 \%}$ & 10.69 & 10.11 & 9.34 & 8.34 & 8.08 & 7.62 & 6.75 & 6.57 & 4.51 & 3.64 & 1.61 & ND & ND \\
\hline $\mathbf{2 \%}$ & 10.69 & 10.18 & 9.59 & 9.04 & 9.04 & 8.71 & 8.57 & 7.96 & 7.04 & 6.32 & 5.49 & 4.71 & 4.32 \\
\hline $\mathbf{2 . 5 \%}$ & 10.69 & 10.20 & 9.65 & 9.11 & 9.08 & 8.72 & 8.62 & 7.94 & 7.26 & 6.58 & 5.68 & 4.68 & 4.26 \\
\hline No PVP & 10.69 & 10.18 & 9.59 & 9.04 & 8.97 & 8.69 & 8.59 & 7.76 & 6.40 & 5.54 & 3.96 & 3.51 & 3.51 \\
\hline
\end{tabular}

Fig.1 Viable count of isolate LN-1 at different concentrations of PVP for a period of one year

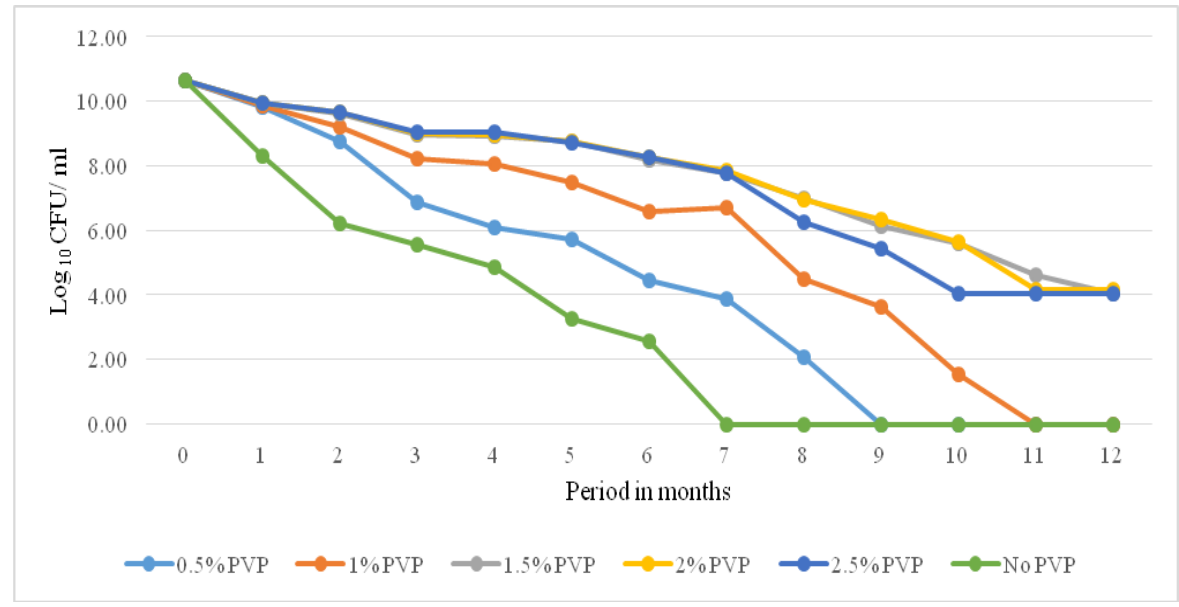

Fig.2 Viable count of isolate LN-14 at different concentrations of PVP for a period of one year

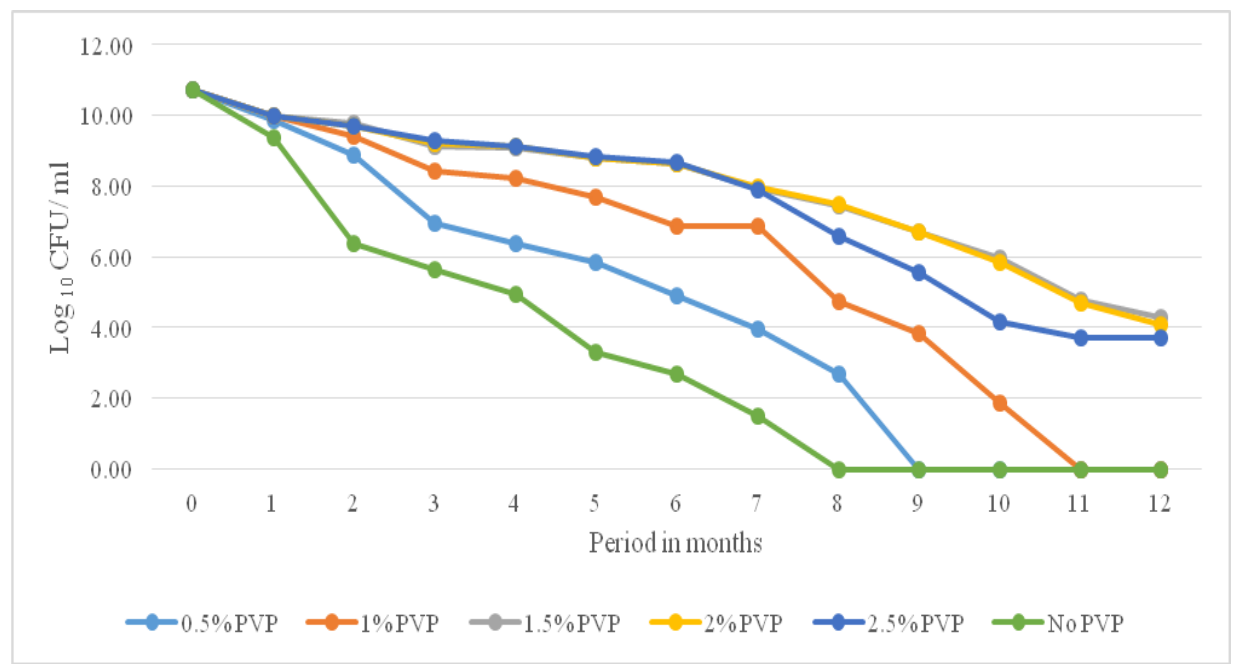


Fig.3 Viable count of isolate LN-19 at different concentrations of PVP for 1 year

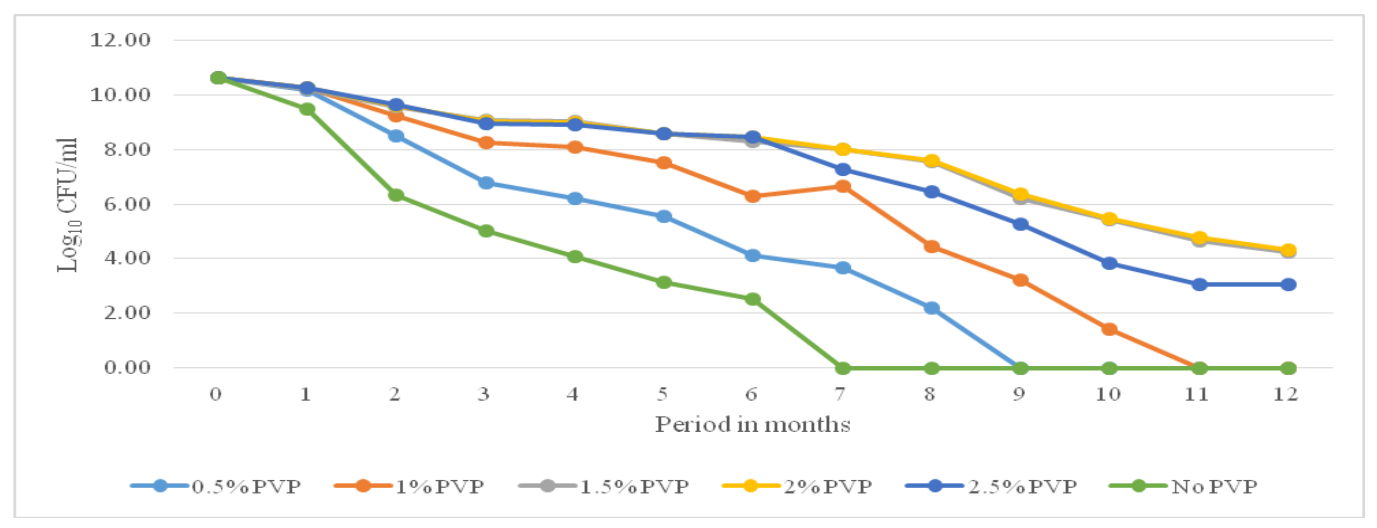

Fig.4 Viable count of lignolytic consortium at different concentrations of PVP for 1 year

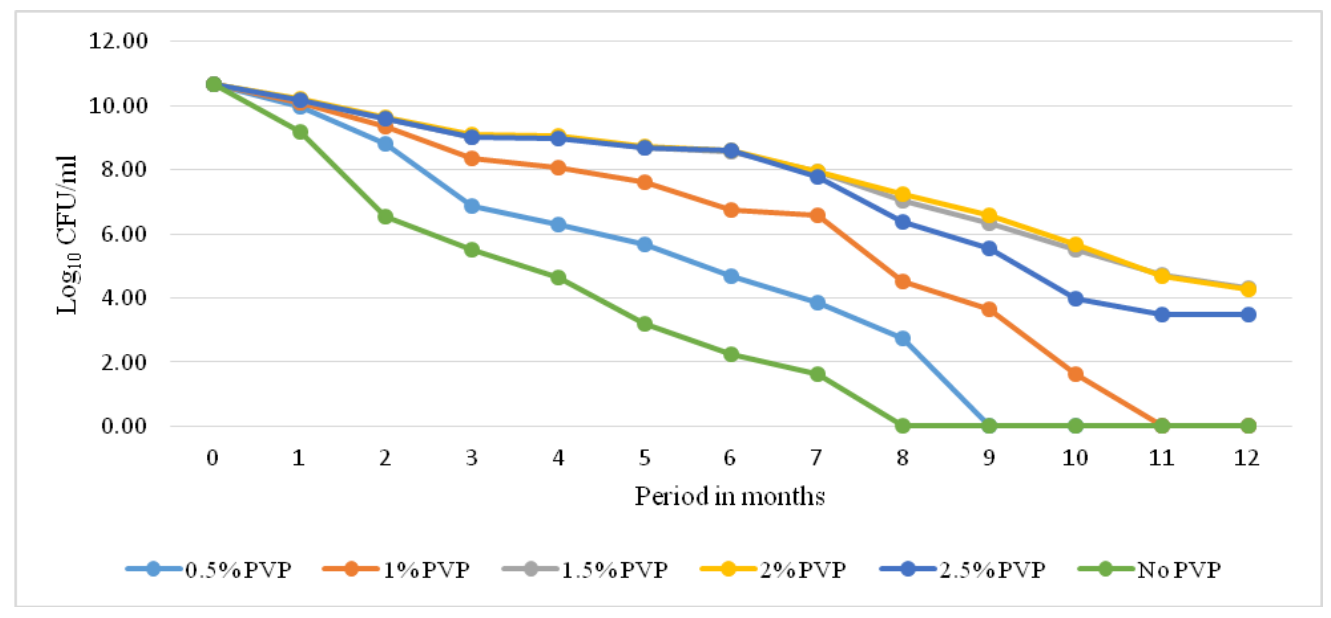

In Control, viable cells were not detected from $8^{\text {th }}$ month onwards, whereas, in formulations with $0.5 \%$ and $1 \%$ PVP from $9^{\text {th }}$ and $11^{\text {th }}$ month onwards, no cell was detected. All the treatments except formulations containing PVP $1.5 \%$ and above, the viability count was observed to reduce sharply. As shown in Table $3 \&$ figure 3 , isolate $\mathrm{LN}-19$ also followed the same trend. The viable count of isolate $\mathrm{LN}-19$ dropped rapidly in formulations added no PVP (10.71 to $5.64 \mathrm{log}$ $\left.{ }_{10} \mathrm{CFU} / \mathrm{ml}\right), 0.5 \%$ PVP (10.71 to $6.97 \log 10$ $\mathrm{CFU} / \mathrm{ml}$ ) and 1\% PVP (10.71 to $8.83 \log 10$ $\mathrm{CFU} / \mathrm{ml}$ ) from third month onwards. From $7^{\text {th }}$ month onwards, no viable spore was detected in the formulation without any PVP. In formulations added with $0.5 \%$ and $1 \%$ PVP, viable spore was not detected from $9^{\text {th }}$ and $11^{\text {th }}$ month respectively. The formulation containing PVP at $1.5 \%, 2 \%$ and $2.5 \%$ were recorded to maintain viable cells for 12 months.

As displayed in Table 4 and figure 4, the consortium of three lignolytic fungal isolates was found to be viable in formulations containing $1.5 \%, 2 \%$ and $2.5 \%$ PVP till $12^{\text {th }}$ month. Control was not detected with viable cells from $8^{\text {th }}$ month onwards, whereas, in formulations with $0.5 \%$ and $1 \%$ PVP from $9^{\text {th }}$ and $11^{\text {th }}$ month onwards no cell was detected. In all the treatments, except formulations 
containing PVP $1.5 \%$ and above, the viable count was observed to reduce sharply. So, in this experiment, PVP at $1.5 \%$ was observed to be most optimal for maintaining the viability of lignolytic consortium upto one year. Gopal and Baby (2016) reported that, PVP at $2.5 \%$ concentration was the most suitable amendment for improving the shelf life of phosphate solubilizing bacteria. Polyvinylpyrrolidine (PVP) contributes to metabolism of organism by maintaining water around the cells (Singleton et al., 2002, Deaker et al., 2004). PVP in the presence of gum arabic is known to protect cells against toxic principles (Mugnier and Jung, 1985). From the present study, it can be concluded that a formulation containing 3\% jaggery and $0.05 \%$ yeast extract amended with $1.5 \%$ PVP is the most suitable and effective to maintain the shelf life of all the three lignolytic fungi for 12 months, and maintain viable cells up to a period of 12 months.

\section{Acknowledgements}

We thank ICAR-Indian Agricultural Research Institute, New Delhi for providing fellowship towards the $\mathrm{PhD}$ program of first author. The authors also thank the Division of Microbiology, IARI New Delhi for providing the laboratory facilities.

\section{References}

Borah, N., Barua, R., Nath, D., Hazarika, K., Phukon, A., Goswami, K. and Barua, D. C. (2015) Low energy recalcitrant rice stubble management through in Situ decomposition. Procedia Environmental Sciences. 35: 771 780.

Deaker, R., Roughley, R. J. and Kennedy, I. R. (2004) Legume seed inoculation technology A review. Soil Biology \& Biochemistry. 36: 1275-88.

Gopal, S. K. and Baby, A. (2016) Enhanced shelf life of Azospirillum and PSB through addition of chemical additives in liquid formulations. International Journal of Science, Environment and Technology, 5(4): 2023-2029.

Hiremath, P, Nuguru,K, Vivek Agrahari V,(2019) Material Attributes and Their Impact on Wet Granulation Process Performance, Chapter 8, In: Editor(s): Ajit S. Narang, Sherif I.F. Badawy, Handbook of Pharmaceutical Wet Granulation, Academic Press, pp. 263-315,

ISBN

9780128104606,https://doi.org/10.101 6/B978-0-12-810460-6.00012-9. (http://www.sciencedirect.com/science /article/pii/B9780128104606000129)

Kumar, P., Kumar, S., Joshi, L. (2015) Socioeconomic and environmental implications of agricultural residue burning: A case study of Punjab, India, ISBN 978-81-322-2014-5

Lewis, J. A., Papavizas, G. C (1985) Application of Trichoderma and Gliocladium in alginate pellets for control of Rhizoctonia damping-off. Plant Pathology, 36:571-577

Mugnier, J. and Jung, G. (1985) Survival of bacteria and fungi in relation to water activity and the solvent properties of water in biopolymer. Applied and Environmental Microbiology. 50. 10814.

San Martin, R., Latorre, B. A., Agosin, E., Vasquez, G. S. (1997) Effectiveness of conidia of Trichoderma harzianum produced by liquid fermentation against Botrytis bunch rot of table grape in Chile. Crop Protection. 16:209-214.

Sharma, M. P., Sharma, S. K. and Dwivedi, A (2010) Liquid biofertilizer application in soybean and regulatory mechanisms. (April): Agricultural Today.44-45. 
Singleton P.W., Keyser, H. H. and Sande, E. S. (2002) Development and evaluation of liquid inoculants. In: Inoculants and nitrogen fixation of legumes in Vietnam (ed.) D Herridge, ACIAR proceedings, 109: 52-66.

Vendan, R. T. and Thangaraju, M. (2006) Development and standardization of liquid formulation for Azospirillum bioinoculant. Indian Journal of Microbiology 46: 379-387.

Vibha and Sinha, A. (2007), Variation of Soil Mycoflora in Decomposition of Recalcitrant rice stubble from Ricewheat Cropping System. Mycobiology. 35(4): 191-195.
Vijayendra, S.V.N. Devendrabansal, M.S.Prasad, Nand, K. (2001). Jaggery: a novel substrate for pullulan production by Aureobasidium pullulans CFR-77. Process Biochemistry 37. 359-364. 10.1016/S0032-9592(01)00214-X.

Vikineswary, S., Kuthubutheen, A. J., Ravoof, A. A. (1997) Growth of Trichoderma harzianum and Myceliophthora thermophila in palm oil sludge. World Journal of Microbiology Biotechnology, 13:189194.

\section{How to cite this article:}

Sruthy, K. S. and Livleen Shukla. 2021. Development of a Liquid Formulation of Lignolytic Fungi for Increased Shelf Life. Int.J.Curr.Microbiol.App.Sci. 10(01): 934-940.

doi: https://doi.org/10.20546/ijcmas.2021.1001.112 